\title{
THE TOXIC EFFECT OF CERTAIN ACIDS UPON TYPHOID AND COLON BACILLI IN RELATION TO THE DEGREE OF THEIR DISSOCIATION.*
}

\author{
C.-E. A. WINSLOW AND E. E. LOCHRIDGE.
}

(From the Biological Laboratories of the Massachusetts Institute of Technology.)

\section{INTRODUCTION.}

THE researches of the physical chemists, under the leadership of Arrhenius and Nernst, have shown that certain substances in aqueous solution become dissociated or broken up into electrically charged part-molecules (atoms or groups of atoms), which are called ions. The extent to which this occurs varies with different substances and is greatest in the most dilute solutions. With strong acids and bases, and their salts, it is practically complete at a strength of $0.00 \mathrm{I}$ normal. With such solutions it is evident that any effect, chemical or physiological, which they exert, must be due to the dissociated ions. The properties of a dilute solution of sodium chloride are the properties of sodium and chlorine ions, and the properties of hydrochloric acid, of hydrogen and chlorine ions. By the comparison of a series of properly selected compounds it is easy to determine the specific influence of each ion. The study of the toxic action of various substances in the light of these facts promises to be of great assistance in the development of a rational theory of disinfection.

The first definite statement of the relation between dissociation and disinfectant power with which we are familiar was made by Dreser. This author (Dreser, I893), in a study of the pharmacological value of various salts of mercury, found that the double hyposulphite of mercury and potassium was much less poisonous than other compounds containing the same amount of mercury, and explained the phenomenon by the fact that this salt on dissociation does not set free mercury ions, but breaks up into potassium at the cathode and $\mathrm{Hg} \mathrm{S}_{4} \mathrm{O}_{6}$ at the anode. His experiments were made on yeast cells, frogs, and fishes. In the former case he found it possible to prevent all development in a yeast culture by mercury salts, and

*Received for publication March 5, I 906. 
then by the addition of potassium hyposulphite to permit fermentation without precipitating any of the mercury, simply by the formation of the differently dissociated double salt.

Scheurlen and Spiro (1897) confirmed the conclusions of Dreser as to the correlation between dissociation and disinfectant action among the mercury salts, and extended them to cover certain compounds of iron. At the same time they maintained that in other cases (the ethylchlorid and ethylsulphate of mercury) strong disinfectant action was apparently due, not to free ions, but to the undissociated molecule.

A number of phenomena which had long been empirically familiar in bacteriology found an easy explanation on the electrolytic theory of disinfection. The effect of temperature in increasing the activity of disinfectants, for example, had been pointed out by Koch (I88I), and later by Behring ( 1890 ) and Heider ( 1892 ), and many others. It was at once obvious that this might be due in some cases to the increased dissociation at high temperatures. It would be well worth while today to see how far the increased activity of disinfectant runs quantitatively parallel to its dissociation. Again, Minervini (I898), and other investigators, have shown that various antiseptic agents (carbolic acid, chromic acid, mercuric chloride, and silver nitrate in Minervini's experiments) are much less active in alcoholic than in aqueous solutions. This fact, too, is easily explicable as due to the diminished dissociation in such solvents.

The relation between dissociation and toxicity was put upon a sound quantitative basis by the work of Krönig and Paul, first published in 1896 (Paul and Krönig, I896), and in fuller detail in the next year (Krönig and Paul, I897). These authors carried out an elaborate series of experiments on the disinfectant action of various salts, bases, and acids in the light of the new conclusions of physical chemistry. The details of the investigation were arranged with the greatest care in order to secure comparable results. Spores of Bacillus anthracis and vegetative cells of Micrococcus aureus were used, dried on Bohemian garnets. By using a definite number of garnets of a certain size shaken up with a suspension of an agar culture, after filtering through paper, and carefully drying, it was found possible to expose approximately the same number of cells in each experiment. 
The garnets were dried for $\mathrm{I} 2$ hours at $7^{\circ}$ and exposed in platinum sieves to the action of the disinfectant solution studied. The temperature was kept constant at $18^{\circ} \mathrm{C}$. during the experiment, and after the desired time had elapsed the excess of disinfectant was carefully removed by appropriate reagents (neutralization of acids and bases, precipitation of heavy metals with ammonium sulphide, etc.). After thorough rinsing, the garnets were shaken up with water to detach the cells, which were then plated on agar. No attempt was made accurately to fix a killing point by testing a long series of dilutions of each disinfectant, and no exact calculations were made of dissociation. In a general way, however, the number of spores of $B$. anthracis which developed after treatment for a given time varied inversely with the amount of dissociation. Thus in the study of metallic salts it appeared that the activity of various compounds of mercury, silver, copper, and gold was greatest in those actively dissociated, and decreased in those which yield less free metallic ions. Solutions of mercuric chloride and silver nitrate, in alcohol, where no dissociation occurs, showed almost no disinfectant action. Furthermore, the toxic action of a salt having poisonous metallic ions was markedly diminished by the presence of a non-toxic salt of the same acid. This is in accord with physico-chemical theory; in any solution the ratio between the undissociated molecules and the product of free anions and cations is constant, so that the addition of sodium chloride to mercuric chloride keeps the proportion of chlorine ions the same, but replaces a portion of the mercury ions by those of sodium. So it appeared in Krönig and Paul's work that successive additions of sodium chloride to mercuric chloride progressively increased the number of colonies developing after the usual treatment. In the study of different salts of the same metal it was found that the acid radical may also exercise considerable influence on the disinfecting power.

With bases Krönig and Paul found the same general relation to hold, ammonium hydroxid, which is weakly dissociated, being a much less active disinfectant than the corresponding compounds of potassium, sodium, and lithium. The authors noted in a general way a diminution of disinfectant action in the presence of organic compounds. The decrease was most marked with the halogens and 
oxidizing agents, and less with acids and bases. Disinfectants themselves of organic nature were least affected.

The particular phase of the subject with which we are especially concerned, the disinfectant action of the acids, was not exhaustively treated in this investigation. One series of experiments was made with normal and half-normal solutions, in which it was found that hydrofluoric, nitric, and trichloracetic acids in normal strength killed all the anthrax spores in 120 minutes. Normal chloric, hydrobromic, and hydrochloric acids and half-normal oxalic acid left a few spores alive after eight hours. Normal sulphuric acid was a little less effective, and normal phosphoric, formic, and acetic acids left large numbers of organisms alive after eight hours. Hydrocyanic acid in normal strength showed little action even after 30 hours. The investigators conclude that there is a general relation between the action of the acids and the amount of dissociated hydrogen present; but there appear many exceptions to a strict parallelism. The authors attribute these exceptional effects to the anion or the undissociated molecule, and point out that in more dilute solutions they tend to disappear. Thus, 0.06 normal solutions of hydrochloric, chloric, nitric, and trichloracetic acids showed about the same disinfectant action, apparently due to the presence of an approximately equal amount of dissociated hydrogen.

At a still earlier period a somewhat similar series of investigations to those of Paul and Krönig had been carried out in another field. This was a study of the relation between toxicity and dissociation as measured by the effect of various salts and bases, and a long series of organic and inorganic acids, on the higher plants, by Kahlenberg and True (1896). Their method consisted in determining the maximum strength of solution in which seedlings of Lupinus albus could grow. The seedlings were exposed for 15 to 24 hours, and their condition determined by their general appearance and by the growth which had taken place. These plants proved very sensitive to the action of dilute acid, a strength of from 0.00008 to 0.00064 normal killing them in almost every case. It is interesting to note that boric acid was endured in Io times this strength. In general, the poisonous action ran parallel with the degree of dissociation, but certain of the organic acids showed relations of their 
own. The authors concluded that "in the case of plants the toxic action of solutions of electrolytes, when dissociation is practically complete, is due to the action of the ions present. When dissociation is not complete, the undissociated part of the electrolyte may also exert a toxic effect." Heald ( 1896 ) extended the work of Kahlenberg and True to the seedlings of three other flowering plants, and reached the same general conclusions. All these authors pointed out clearly that the effect of the common mineral acids is due to hydrogen alone, since their anions have almost no strong toxic action when neutral salts are used.

The next work along these general lines was carried out in another field of botany by Stevens ( 1898 ), at the University of Chicago, the measure of viability used being the germination of fungus spores. A study had been made by Wüthrich (1892), at a much earlier date on the toxicity of metallic salts and acids for the spores of fungi; and Maillard ( 1898 and 1899 ) at about the same time reported experiments on the inhibition of the growth of Penicillium by copper salts. In Stevens' experiments the spores were inoculated into hanging-drop preparations of the solutions tested, and examined for development after 24 hours. The five organisms used exhibited marked differences in their susceptibility, although all were much less affected than the phanerogamous seedlings, requiring a strength of $0.01-0.02$ normal acid to inhibit germination. The relative toxic effect of various substances was not unlike that observed by Heald and Kahlenberg and True. Mercuric chlorid and various copper salts proved most fatal, the acids and cyanides being less active. By the comparison of various substances it appeared that of the anions, $\mathrm{CN}, \mathrm{CrO}_{4}, \mathrm{Cr}_{2} \mathrm{O}_{7}$, and $\mathrm{OH}$ are poisonous, and of the cations, $\mathrm{Hg}$, $\mathrm{Cu}$, and $\mathrm{H}$, while the halogens and $\mathrm{SO}_{4}$ in dilute solutions exert no influence.

A still more exhaustive study of the effect of toxic agents upon the fungi was made by Clark in the next year (Clark, I899). This investigator followed the same general method as that of Stevens, exposing spores in hanging-drop cultures to the activity of the agents to be tested. The cultures were divided into four classes: those which grew normally, those which showed irregular or retarded growth, those which failed to develop in the medium tested, but grew after 
transfer to fresh beef infusion, and those which entirely succumbed to the action of the toxic substances. The wide difference between the concentration of acid producing, respectively, injury, inhibition, and death was one of the most interesting results of these experiments. As in Stevens' work, it was apparent that the fungi are extremely resistant to disinfectants, and it was necessary to use somewhat concentrated solutions, from 0.008 to 0.287 normal acid, for killing. It is perhaps partly for this reason that, as the author says, "in this study no new evidence has been adduced supporting the theory that the chemical activities of a substance are due wholly or chiefly to the ionized portion." On the other hand, it was held that "in the case of several acids, ionization lessens the chemical activities toward the substances involved in the life-processes of the plant." This conclusion is based on calculations of the specific toxicity of each ion and molecule, obtained by comparing the effects of different compounds varying from each other in one element or group. Thus, hydrochloric acid in the solutions used was over go per cent dissociated and since experiments with the similarly dissociated chloride of potassium showed this salt to be practically non-toxic, it is evident that its action was due to the combined effect of the hydrogen ion and the undissociated molecule. Nitric acid, dissociated in the same proportion was much more toxic. Since hydrogen ions are equal in the two cases and since the $\mathrm{NO}_{3}$ ion is harmless, as shown by experiments with neutral salts, the increased effect must be due to the undissociated part of the molecule of nitric acid. Clark calculates that the toxic value of one molecule of undissociated $\mathrm{HNO}_{3}$ is 7.7 times that of an ion of hydrogen, so that the acid actually loses nearly seven-eighths of its disinfectant power by becoming ionized.

The effect of sulphuric acid was about the same as that of hydrochloric; since it is less dissociated, the author attributes an appreciable influence to the anion, $\mathrm{HSO}_{4}$. Acetic acid, at the strength used, is only 2 per cent dissociated, so that its high toxic effect is due to the un-ionized molecule.

The results obtained in this series of experiments with hydrocyanic acid are also interesting. Krönig and Paul (1897) found this acid almost without effect on anthrax spores, while Kahlenberg and True (1896), on the other hand, record very strong toxic action 
on the seedlings of higher plants. In Clark's experiments it proved far more fatal than any other acid, being 7o times as active as hydrochloric. The molecule at the concentrations used is probably only slightly dissociated.

In some ways the most important work upon this subject was the very careful study made by Bial, of the antiseptic action of the hydrogen ion of dilute acids upon yeast. He first became interested in the problem from a consideration of the causes which allow production of gas in the stomach, and carried out his earliest experiments by observing the gas formation in yeast cultures in the presence of various substances present in the normal gastric juice. This series of studies (Bial, I897) showed that the presence of albuminoid substances or of sodium chloride effected a marked restriction of the antiseptic action of hydrochloric acid. Bial at this time did not apply physico-chemical theories to the explanation of these phenomena; but in another contribution he made a fuller study of the problem. His later experiments (Bial, IgO2) were again made with yeast cells, cultivated in fermentation tubes filled with grape-sugar solution to which various amounts of acid had been added; the antiseptic action was inversely registered by the amount of gas produced. The advantage of this method is its great delicacy; the fermentative power of the yeast responds to such extremely minute quantities of acid that the ionic effects are not complicated by other actions which appear in stronger solutions. Bial did not make exact calculations of the amount of dissociated hydrogen necessary to inhibit the yeast, but he found that a general relation existed between the ionization and the antiseptic action. The strongly dissociated acids-hydrochloric, sulphuric, nitric, and trichloracetic - entirely stopped the action of the yeast in concentrations of between 0.005 and 0.008 normal. Acids of an intermediate grade-phosphoric, formic, and oxalic-accomplished the same effect when 0.0 r normal; while acids still less dissociated-acetic, benzoic, and butyric-stopped all fermentation only when 0.04 to 0.07 normal. The most striking feature of Bial's work was a series of experiments on the diminution of the antiseptic action of acids by the addition of neutral salts whose action is to decrease the dissociation of the acidic hydrogen. A solution of 0.01 normal formic acid and 0.3 
normal sodium formate showed active fermentation, as did a solution of 0.0166 normal hydrochloric acid and 0.2 normal sodium chloride. The same phenomenon was observed with oxalates, nitrates, sulphates, and acetates. An exhaustive study in the case of hydrochloric acid showed that, while a certain amount of sodium chloride diminished the toxicity of the acid, a much larger amount actually increased it. Bial attributes this to a catalytic action of chlorine ions, but it seems to us that the facts may be explained more simply by the direct inhibiting effect of the sodium chloride and its ions. Bial'found that twice normal sodium chloride without any acid prevented fermentation; and it is quite possible, in dealing with living organisms, that the combined effect of the acid and the chloride would be inhibitory at inncentrations which with either acid or base alone might allow fermentation to go on. Bial studied also the effect of hydrochloric acid and sodium chloride in the presence of peptone, and found that the yeast would bear more of the salt than in the presence of acid alone.

The experiments of Paul and Krönig demonstrated clearly that in certain solutions disinfectant action runs parallel with the presence of dissociated ions. The work upon the higher plants and the mold fungi confirmed these results, but showed that in other cases the undissociated molecule is of great importance. Bial's studies brought out clearly the influence of neutral bodies, inorganic salts or proteids, in diminishing disinfectant ${ }^{*}$ action by decreasing dissociation.

The problem is, of course, complicated by still other chemical interactions which are more obscure. For example, Scheurlen, (I895), Beckmann (1896), Römer (1898), and Spiro and Bruns (1898) have shown that in the case of phenol and certain other organic disinfectants the addition of sodium chloride greatly increases toxic action. Still another factor which affects disinfectant power has been brought out in recent years by Nägeli (1893), and other observers-the presence of suspended solid particles of neutral character. In the most recent communication upon this subject by True and Oglevee (1905) it was shown that the toxic effect of metallic salts upon Lupinus may be entirely counteracted by the presence of finely divided particles of sand, glass, filter paper, coal, starch, or paraffin. On the other hand,the toxic effect of organic disinfectants 
-phenol, thymol, and resorcinol-was affected only to a barely appreciable degree. The action when it occurs is explained by the power of suspended particles to remove dissolved substances by a process of adsorption, and the possibility suggests itself that the removal of ions by large organic molecules in true or colloidal solutions may be of an analogous character. Whatever the cause, this phenomenon must prove of far-reaching importance in bacteriology. Such facts as the observed multiplication of bacteria, when water samples are stored in glass bottles, may be the result of a removal of inhibiting substances by the adsorptive action of glass surfaces.

A considerable body of evidence in the field of animal physiology bears out these conclusions obtained from the study of bacteria and other plants. A fairly full summary of this literature may be found in the reviews of Cohen (1903) and Hamburger (1904). The work of Kahlenberg (1898) and other observers, who have shown that the taste of dilute solutions is in many cases due to the specific properties of the dissociated ions, is of interest. Studies which have been frequently cited were made by Loeb (1897 and 1898 ), and recently reprinted (Loeb, I905), on the influence of free ions upon frog's muscle. The gastrocnemius muscle absorbs water and increases its weight in the presence of slight traces of acids or alkalis, and Loeb concluded that for the inorganic acids and bases this increase in weight is solely a function of the number of hydrogen and hydroxyl ions in the unit of volume. This sweeping conclusion is hardly borne out by his experiments. With the organic acids there was no relation whatever. Trichloracetic acid, almost entirely dissociated, and lactic acid, with only i per cent dissociation, gave practically the same results. With a series of II different organic acids of every degree of dissociation, the individual variation in weight-increase, with 0.009 normal solutions, ranged only between 3.9 per cent and 7.2 per cent.

A very significant line of physiological investigation concerns the binding of free ions by organic molecules of large size. In one of the most recent communications on this subject, Stiles and Beers (1905) have shown that the effect of calcium chloride, barium potassium chloride, and sodium nitrite upon plain, cardiac, and striped 
muscle of the frog, terrapin, and guinea-pig was reduced from onehalf to three-fourths in the presence of white of egg, partially dialyzed serum, peptone, or starch. In some cases a combination between the inorganic body and the proteid has been demonstrated by freezingpoint determinations, but in other cases particularly with the neutral salts, this has not been shown. As the authors suggest, these experiments point to the existence of "physiological compounds which are not demonstrable at all by chemical methods, but only by the reactions of living tissues."

\section{OBJECT AND METHODS OF THE PRESENT INVESTIGATION.}

The present investigation was begun with the intention of determining the effect of acid wastes in sewage upon the viability of the typhoid bacillus under practical conditions. It soon appeared, however, that the problem was too complex to be attacked in any general way without the preliminary determination of certain of the individual factors involved, under definitely controlled conditions. We have therefore attempted to find the disinfectant power of two mineral acids and two organic acids upon the typhoid bacillus in tap water and in the presence of peptone, and have controlled these experiments by a parallel series with the colon bacillus. The results, besides their specific value as determinations of the reactions of these two organisms to dilute acids, have a certain interest in relation to the general theory of disinfection. In all the experiments reviewed above, except Bial's, the acids used were tested in only a few widely differing strengths, so that the parallelism between disinfectant action and dissociation was not established with any great exactness. In the work of Krönig and Paul on anthrax spores and the various studies on the mold fungi, it was necessary to use such strong solutions that ionic effects were largely masked by the influence of the undissociated molecule, and in the studies of Kahlenberg and True and Heald on the phanerogams it was evident that with such complex organisms many other factors than the direct effect on protoplasm come into play. There was room, therefore, for a series of experiments on organisms sensitive to very dilute acids, carried out in sufficient detail to show definitely the relations between toxicity and dissociation. 
With the view of securing exact quantitative results, we adopted the method of exposure to the acid tested, in a suspension from which samples were directly plated. This process has the obvious defect of permitting a certain amount of the disinfectant to be carried over to the plate, where it may exert an antiseptic action. We have really measured the combined disinfectant action in the suspension and possible antiseptic action in the plate. The action of organic matter in decreasing toxicity, shown by our experiments, must greatly reduce any such action in the plate.

The procedure in each experiment was as follows: A series of bottles, each containing too c.c. of sterile water (or peptone solution), was arranged in a row, and to each bottle was added a different amount of standardized acid from a graduated pipette. The amount of water in each bottle was measured at the end of the experiment, in order to obtain the exact strength of the solution. Immediately after the addition of the acid there was added to each bottle I c.c. of a fresh aqueous suspension of the bacteria tested. After standing for 40 minutes, lactose agar plates were made in duplicate, from the acidified bottles, and from controls with no acid. Colonies were counted after 24 hours' incubation at $37^{\circ} \mathrm{C}$.

Forty minutes was selected, after some preliminary experiments, as the best period of exposure to the acid, since it gave sharper results than a shorter time. In the tests reported in the accompanying tables there was not a variation from the 40 minutes of more than one minute in most of the samples. The series for B.typhi in water, with $\mathrm{HCl}$, were also examined after roo minutes, and after 24 hours. In the sample containing 48 parts per million of sulphuric acid, there was, after 40 minutes, 59.3 per cent removal of B. typhi; after roo minutes, 88.I5 per cent removal; after 24 hours, Ioo per cent removal. The sample containing 92.9 parts per million of sulphuric acid removed after 40 minutes 92.97 per cent; after Ioo minutes, $99.99+$ per cent; after 24 hours, 100 per cent. The removal was roo per cent in all of the samples containing larger amounts of acid after I03 minutes, and in all of the samples after 24 hours.

The temperature factor was of considerable importance, and care was taken to keep conditions uniform. No agar was poured with a temperature greater than $50^{\circ} \mathrm{C}$. It was found that a rise in tem- 
perature in the presence of the acid was very fatal in its effect on the bacteria.

The typhoid culture used was obtained from the Massachusetts General Hospital, where it had been isolated from the spleen of a clinically typical case of typhoid fever; the colon bacillus was isolated in the laboratories of the Institute, and both gave all characteristic reactions. Twenty-four-hour agar-slant cultures were used in all cases.

The tables have been prepared to show, in the first column, the parts per million of the acid, and in the second column the parts per million of acidic hydrogen or, more accurately, of replaceable hydrogen. The third column shows the strength converted into terms of normality. The percentage dissociation of the acids at each dilution is given in the fourth column, and the actual parts of dissociated hydrogen in the fifth. The last two columns show the initial number of bacteria used as shown by blank controls and the percentage reduction after 40 minutes.

The tables show in general that with increasing quantities of disinfectant the bacterial reduction proceeds rapidly up to a certain point. After 99 per cent of the organisms have been killed, however, it takes a very considerable further increase of acid to produce sterilization. This is a point of very fundamental importance, and one which has been observed in studying the effect of such various agents upon the bacteria, that it deserves special attention. Sedgwick and one of us (Sedgwick and Winslow, I902) have called attention to the persistence of a few specially resistant individuals when typhoid bacilli are exposed to the action of cold. After $\mathrm{r}_{4}$ days of exposure to freezing temperature 99.8 per cent of the organisms were killed, but after three months a few still survived. Johnson's tables of the reduction of typhoid and colon bacilli by copper salts (Johnson, 1905) show the same phenomenon, although he does not comment upon it specifically. More recently, Frost and Swenson (I906), and Gage and Stoughton (I906), have emphasized this peculiar phenomenon, in connection with resistance to high temperatures. The former authors, working with $B$. dysenteriae, found that "the majority of the cells were killed between $55^{\circ}$ and $60^{\circ}$, but that frequently a relatively small number, possibly one individual 
in a hundred thousand or a million, may persist at much higher temperatures, even $70^{\circ} . "$ Gage and Stoughton in their conclusions point out that "the great majority of the bacteria in any $B$. coli cultures are destroyed by five minutes' exposure to some temperature between $50^{\circ}$ and $60^{\circ} \mathrm{C}$. A few individuals, however, in each culture will survive much higher temperatures, in some cases remaining alive after exposure to $90^{\circ} \mathrm{C}$. The very close range (about $10^{\circ} \mathrm{C}$.) of temperature at which the destruction of the majority of the individual bacteria occurred, as compared with the considerable range (about $35^{\circ} \mathrm{C}$.), in the temperatures at which complete sterilization was effected would indicate that the determination of the majority death-point would be of more value in species identification than is the determination of the absolute thermal death-point as at present employed."

Altogether it seems clear that among what are ordinarily considered non-sporing bacteria there exists a small proportion of individuals having specially high resistant powers against unfavorable conditions. The absolute death-point for these resistant forms is difficult to determine accurately on account of their small numbers and the consequent chances that they may be overlooked. We are inclined from our experience to agree with Gage and Stoughton as to the superior value for many purposes of the majority death-point (99 per cent), and we shall lay special stress on this in interpreting our results.

3. THE DISINFECTANT ACTION OF HYDROCHLORIC ACID AND SULPHURIC ACID UPON B. TYPHI AND B. COLI.

Hydrochloric acid and sulphuric acid were chosen as types for the study of strong mineral acids, and the experiments were carried out as described above. The water used was Boston tap water, containing before sterilization about 40 parts per million of residue, I5 parts of hardness, 0.0r5 part of free ammonia, and 0.144 part of albuminoid ammonia. The results are shown in Tables I-4.

The 99 per cent killing-point with the hydrochloric acid is reached at a strength of 0.0077 normal, with 7.49 parts of dissociated hydrogen per million, and the absolute killing-point, as nearly as it can be retermined, with a 0.0123 normal solution containing Ir.80 parts 
TABLE I.

Action of Hydrochloric ACid on B. coli in Tap Water.

\begin{tabular}{|c|c|c|c|c|c|c|}
\hline $\begin{array}{l}\text { Acid Parts in } \\
\mathbf{1}, \infty 00, \infty 00\end{array}$ & $\begin{array}{l}\text { Hydrogen } \\
\text { Parts in } \\
I, \infty 00, \infty 00\end{array}$ & Normality & $\begin{array}{l}\text { Per Cent of } \\
\text { Dissociation }\end{array}$ & $\begin{array}{c}\text { Dissociated } \\
\text { Hydrogen. } \\
\text { Parts in } \\
I, 000,000\end{array}$ & $\begin{array}{l}\text { Bacteria per } \\
\text { c.c. before } \\
\text { Treatment }\end{array}$ & $\begin{array}{l}\text { Percentage Re- } \\
\text { duction of Bacteria } \\
\text { after } 40 \text { Min. }\end{array}$ \\
\hline $\begin{array}{r}38.1 \\
77.6 \\
104.5 \\
149.0 \\
178.9 \\
281.0 \\
298.0 \\
377.0 \\
447.0 \\
515.0 \\
590.0 \\
663.0\end{array}$ & $\begin{array}{r}\mathrm{r} .05 \\
2.13 \\
3.32 \\
4.08 \\
4.90 \\
7.71 \\
8.17 \\
10.61 \\
12.26 \\
\ldots \ldots \\
\ldots \ldots \\
\ldots \ldots\end{array}$ & $\begin{array}{l}0.0010 \\
0.0021 \\
0.0033 \\
0.0041 \\
0.0049 \\
0.0077 \\
0.0082 \\
0.0106 \\
0.0123 \\
\ldots \ldots \\
\cdots \cdots \\
\cdots \cdots\end{array}$ & $\begin{array}{l}98.0 \\
98.0 \\
97.5 \\
97.3 \\
97.2 \\
97.0 \\
96.5 \\
96.4 \\
96.4 \\
96.3 \\
96.3 \\
96.2\end{array}$ & $\begin{array}{r}1.03 \\
2.09 \\
3.24 \\
3.98 \\
4.76 \\
7.49 \\
7.90 \\
10.24 \\
11.80 \\
\ldots \ldots \\
\ldots \ldots\end{array}$ & 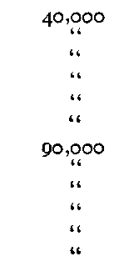 & $\begin{array}{r}\infty .00 \\
45.00 \\
72.85 \\
82.50 \\
97.50 \\
99.87 \\
99.96 \\
99.99 \\
100.00 \\
100.00 \\
100.00 \\
100.00\end{array}$ \\
\hline
\end{tabular}

TABLE 2.

Action of Sulphuric Acid on $B$. coli in Tap Water.

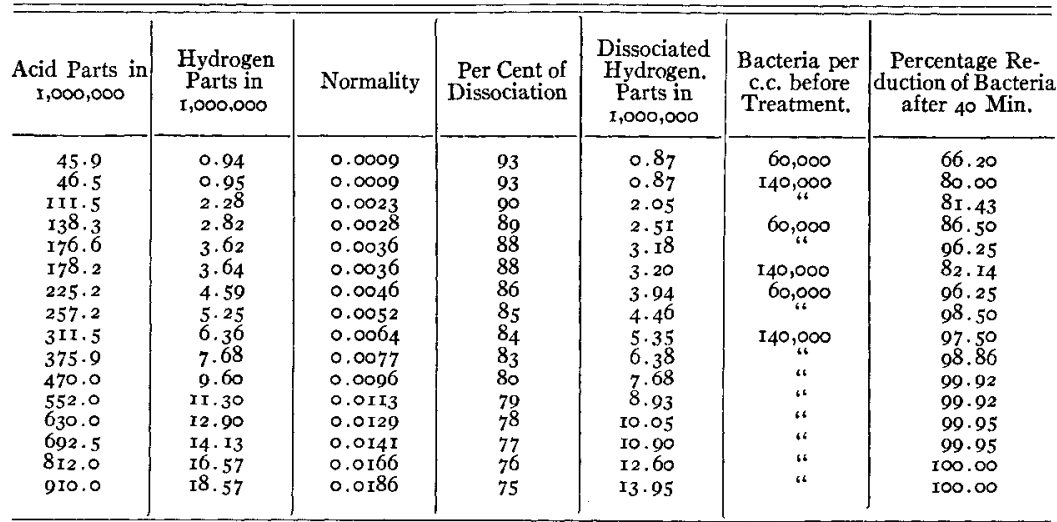

of dissociated hydrogen. With the sulphuric acid the 99 per cent reduction was reached at a strength of 0.0096 normal, with 7.68 parts of dissociated hydrogen, and the 100 per cent reduction at a strength of 0.0166 normal, with I2.6 parts of dissociated hydrogen. These results show a direct relation between disinfectant action and free hydrogen ions. The normal strengths of the killing solutions do not correspond very closely; 0.0077 sulphuric acid failed to do what the same strength of hydrochloric acid did, and 0.0129 and $0.014 \mathrm{I}$ sulphuric acid failed to do what 0.0123 hydrochloric acid did. On the other hand, when we compare dissociated hydrogen, allowing for the greater ionization of the hydrochloric acid, the discrepancies disappear. The same concentrations of dissociated hydrogen, within 
the limits of accuracy of the experiment, produced respectively the 99 per cent and the roo per cent reduction in the two acids.

TABLE 3.

Action of Hydrochloric Acid on B. typhi in TaP Water.

\begin{tabular}{|c|c|c|c|c|c|c|}
\hline$\underset{1,000,000}{\text { Acid Parts in }}$ & $\begin{array}{l}\text { Hydrogen } \\
\text { Parts in } \\
1,000,000\end{array}$ & Normality & $\begin{array}{l}\text { Per Cent of } \\
\text { Dissociation }\end{array}$ & $\begin{array}{c}\text { Dissociated } \\
\text { Hydrogen. } \\
\text { Parts in } \\
1, \infty 00, \infty 00\end{array}$ & $\begin{array}{c}\text { Bacteria per } \\
\text { c.c. before } \\
\text { Treatment }\end{array}$ & $\begin{array}{l}\text { Percentage Re- } \\
\text { duction of Bacteria } \\
\text { after } 40 \text { Min. }\end{array}$ \\
\hline $\begin{array}{r}38.2 \\
75.3 \\
109.5 \\
148.2 \\
182.5 \\
216.8 \\
248.0 \\
275.5\end{array}$ & $\begin{array}{l}1.00 \\
2.06 \\
3.00 \\
4.06 \\
5.00 \\
5.92 \\
6.80 \\
7.54\end{array}$ & $\begin{array}{l}0.0010 \\
0.002 \mathrm{I} \\
0.0030 \\
0.004 \mathrm{I} \\
0.0050 \\
0.0059 \\
0.0068 \\
0.0075\end{array}$ & $\begin{array}{l}98.2 \\
97.9 \\
97.8 \\
97.3 \\
97.1 \\
\ldots \ldots \\
\ldots \ldots \\
\ldots \ldots\end{array}$ & $\begin{array}{l}1.02 \\
2.02 \\
2.94 \\
3.95 \\
4.85 \\
\ldots \ldots \\
\ldots \ldots \\
\ldots \ldots\end{array}$ & $\begin{array}{c}7,050 \\
" 6 \\
" 4 \\
" 1 \\
4 \\
4 \\
" 4\end{array}$ & $\begin{array}{r}79.20 \\
88.10 \\
99.30 \\
99.86 \\
100.00 \\
100.00 \\
100.00 \\
100.00\end{array}$ \\
\hline
\end{tabular}

TABIE 4 .

ACtion of Sulphuric ACID on $B . t y p h i$ in TAP W

\begin{tabular}{|c|c|c|c|c|c|c|}
\hline $\begin{array}{l}\text { Acid Parts in } \\
\mathbf{1}, \infty 00, \infty 00\end{array}$ & $\begin{array}{l}\text { Hydrogen } \\
\text { Parts in } \\
\text { t } 000,000\end{array}$ & Normality & $\begin{array}{l}\text { Per Cent of } \\
\text { Dissociation }\end{array}$ & $\begin{array}{c}\text { Dissociated } \\
\text { Hydrogen } \\
\text { Parts in } \\
I, \infty 00, \infty 00\end{array}$ & $\begin{array}{l}\text { Bacteria per } \\
\text { c.c. before } \\
\text { Treatment }\end{array}$ & $\begin{array}{l}\text { Percentage Re- } \\
\text { duction of Bacteria } \\
\text { after } 40 \text { Min. }\end{array}$ \\
\hline $\begin{array}{r}48.0 \\
92.9 \\
139.4 \\
188.9 \\
223.0\end{array}$ & $\begin{array}{l}0.98 \\
1.88 \\
2.84 \\
3.85 \\
4.55\end{array}$ & $\begin{array}{l}0.0010 \\
0.0019 \\
0.0028 \\
0.0038 \\
0.0045\end{array}$ & $\begin{array}{l}93 \cdot 1 \\
90 \cdot 5 \\
89 \cdot 5 \\
87.0 \\
85 \cdot 5\end{array}$ & $\begin{array}{l}0.91 \\
1.70 \\
2.54 \\
3.35 \\
3.90\end{array}$ & $\begin{array}{c}135,000 \\
4 \\
4 \\
"\end{array}$ & $\begin{array}{r}59.30 \\
92.97 \\
99.99 \\
96.10 \\
100.00\end{array}$ \\
\hline
\end{tabular}

Tables 3 and 4 show that the typhoid bacillus is considerably more sensitive than the colon bacillus in its reaction to an excess of acid. The 99 per cent reduction was reached with hydrochloric acid at a strength of 0.0030 normal and 2.94 parts of dissociated hydrogen, and the 100 per cent reduction with 0.0050 normality and 4.85 parts of dissociated hydrogen. With sulphuric acid the 99 per cent reduction was reached with 0.0028 normality and 2.54 parts of hydrogen, and the roo per cent reduction with 0.0045 normality and 3.90 parts of hydrogen. The fact that the $0.003^{8}$ normal solution of sulphuric acid showed only 96 per cent reduction is one of the abnormalities which unfortunately sometimes occur in bacteriological work. In general, the results show again that the two acids exert the same quantitative effect, although in this case, the solution being weaker and the dissociation of the two acids more nearly the same, the difference between normal strength and concentration of dissociated hydrogen is not clearly shown. 
The critical points derived in these tests are brought together in Table 5. They show that the typhoid bacillus is a little less than half as resistant as the colon bacillus to dilute acids, and that the toxicity of these acids depends, not on their normal strength of acid or on the kind of acid used, but on the number of dissociated hydrogen ions. Between 7.4 and 7.7 parts of dissociated hydrogen effects a 99 per cent reduction of the colon bacillus, and between II. 8 and $\mathrm{I} 2.6$ parts, a Ioo per cent reduction. For the typhoid bacillus the corresponding figures are 2.5-3.0 parts and 3.9-4.9 parts. Since at the dilutions used the hydrochloric acid was over $9^{6}$ per cent dissociated, its effect must have been almost entirely ionic; and since the sulphuric acid at 75 per cent dissociation showed only the toxicity which would have been expected from its dissociated hydrogen, it appears that in this case too the undissociated molecule exerts no appreciable influence. The anions have been shown to be neutral in the experiments of other observers. It is evident, then, that the toxicity of these acids at high dilution is a function of the dissociated hydrogen.

TABLE 5 .

Disinfectant action of Mineral Actos in Tap Water.

\begin{tabular}{|c|c|c|c|c|c|c|c|c|}
\hline & \multicolumn{4}{|c|}{ B. coli } & \multicolumn{4}{|c|}{ B. lyphi } \\
\hline & \multicolumn{2}{|c|}{$99 \%$ Reduction } & \multicolumn{2}{|c|}{ roo\% Reduction } & \multicolumn{2}{|c|}{$99 \%$ Reduction } & \multicolumn{2}{|c|}{ I00\% Reduction } \\
\hline & $\mathrm{HCl}$ & $\mathrm{H}_{2} \mathrm{SO}_{4}$ & $\mathrm{HCl}$ & $\mathrm{H}_{2} \mathrm{SO}_{4}$ & $\mathrm{HCl}$ & $\mathrm{H}_{2} \mathrm{SO}_{4}$ & $\mathrm{HCl}$ & $\mathrm{H}_{2} \mathrm{SO}_{4}$ \\
\hline $\begin{array}{l}\text { Normality............... } \\
\text { Parts per y,ooo,ooo dis- } \\
\text { sociated hydrogen ..... }\end{array}$ & $\begin{array}{l}0.0077 \\
7.49\end{array}$ & $\begin{array}{l}0.0096 \\
7.68\end{array}$ & $\begin{array}{l}0.0123 \\
12.80\end{array}$ & $\begin{array}{l}0.0166 \\
52.60\end{array}$ & $\begin{array}{l}0.0030 \\
2.94\end{array}$ & $\begin{array}{l}0.0028 \\
2.54\end{array}$ & $\begin{array}{l}0.005^{\circ} \\
4.85\end{array}$ & $\begin{array}{l}0.0045 \\
3.90\end{array}$ \\
\hline
\end{tabular}

4. THE DISINFECTANT ACTION OF ACETIC ACID AND BENZOIC ACID UPON $B, T Y P H I$ AND B. COLI.

We next desired to study examples of the incompletely dissociated organic acids. Acetic and benzoic acids were selected as types, and the experiments were carried out as before. The results obtained with benzoic acid are probably somewhat inaccurate on account of the difficulty of securing complete solution. The results are shown in Tables 6-8.

An inspection of these tables shows a marked difference from the results obtained with the mineral acids. With $B$. coli in acetic acid the 99 per cent reduction is reached at a strength of $0.08 \mathrm{I} 2 \mathrm{normal}$, and 


\section{Effect of Acids on Typhoid and Colon Bacilli 563}

TABLE 6.

Action of Acetic ACID on $B$. coli in Tap Water.

\begin{tabular}{|c|c|c|c|c|c|c|}
\hline $\begin{array}{l}\text { Acid Parts } \\
\text { in } 1,000,000\end{array}$ & $\begin{array}{c}\text { Hydrogen } \\
\text { Parts in } \\
x, \infty \infty 0, \infty \infty 0\end{array}$ & Normality & $\begin{array}{l}\text { Per Cent of } \\
\text { Dissociation }\end{array}$ & $\begin{array}{c}\text { Dissociated } \\
\text { Hydrogen. } \\
\text { Parts in } \\
1,000, \infty 00\end{array}$ & $\begin{array}{l}\text { Bacteria per } \\
\text { c.c. before } \\
\text { Treatment }\end{array}$ & $\begin{array}{c}\text { Percentage Re- } \\
\text { duction of Bac- } \\
\text { teria after } 40 \\
\text { Min. }\end{array}$ \\
\hline III. 3 & $\mathrm{I} .85$ & 0.0018 & & $\cdots$ & 60,000 & 00.00 \\
\hline 333.0 & $5 \cdot 54$ & 0.0055 & 6.40 & 0.35 & & 00.00 \\
\hline 552.0 & 9.18 & 0.0092 & $4 \cdot 50$ & $0.4 \mathrm{I}$ & "i & 16.67 \\
\hline 732.0 & 12.20 & 0.0122 & 3.50 & 0.43 & "6 & 23.33 \\
\hline $1,095.0$ & 18.25 & 0.0182 & 3.05 & 0.56 & $"$ & 38.33 \\
\hline $1,386.0$ & 23.20 & $0.023^{2}$ & 2.75 & 0.64 & 46 & 51.67 \\
\hline $1,825.0$ & $30.4 I$ & 0.0304 & 2.45 & 0.75 & 46 & 55.00 \\
\hline $2,260,0$ & 37.70 & 0.0377 & 2.20 & 0.83 & "4 & 56.67 \\
\hline 3,0810 & $5 \mathrm{I} \cdot 40$ & $0.051_{4}$ & I. 90 & 0.98 & 84 & 58.33 \\
\hline $3,698.0$ & 61.70 & 0.0617 & I. 70 & 1.05 & " & 63.33 \\
\hline $4,800.0$ & 80.20 & 0.0802 & I. 50 & I. 20 & " & 91.00 \\
\hline $4,875.0$ & 81.25 & 0.0812 & I. 50 & I. 2 I & 90,000 & 99.99 \\
\hline $5,610.0$ & 93.50 & 0.0935 & I. 35 & I. 26 & & 100.00 \\
\hline
\end{tabular}

TABLE 7.

Action of Benzoic Acid on B. coli in Tap Water.

\begin{tabular}{|c|c|c|c|c|c|c|}
\hline $\begin{array}{l}\text { Acid Parts } \\
\text { in } 1,000,000\end{array}$ & $\begin{array}{l}\text { Hydrogen } \\
\text { Parts in } \\
x,>00,000\end{array}$ & Normality & $\begin{array}{l}\text { Per Cent of } \\
\text { Dissociation }\end{array}$ & $\begin{array}{c}\text { Dissociated } \\
\text { Hydrogen. } \\
\text { Parts in } \\
\tau, \infty 00, \infty 00\end{array}$ & $\begin{array}{l}\text { Bacteria per } \\
\text { c.c. before } \\
\text { Treatment }\end{array}$ & $\begin{array}{c}\text { Percentage Re- } \\
\text { duction of Bac- } \\
\text { teria after } 40 \\
\text { Min. }\end{array}$ \\
\hline 237.9 & 1.95 & 0.0019 & 16.0 & $0.3 \mathrm{I}$ & 70,000 & 00.00 \\
\hline 337.0 & 2.76 & 0.0028 & I3. 6 & $0.3^{8}$ & is & 50.00 \\
\hline 406.0 & $3 \cdot 33$ & 0.0033 & I2. 5 & 0.41 & $"$ " & 60.75 \\
\hline 675.0 & $5 \cdot 54$ & 0.0055 & $9 \cdot 3$ & $0.5^{2}$ & “6 & 67.80 \\
\hline$I, 184.0$ & 9.72 & 0.0097 & $7 \cdot 5$ & 0.73 & 16 & 99.99 \\
\hline $2,425.0$ & 19.90 & 0.0199 & $5 \cdot 4$ & 1.07 & 100,000 & 100.00 \\
\hline
\end{tabular}

TABLE 8.

ACtion of Benzolc ACID on B. typhi in Tap Water.

\begin{tabular}{|c|c|c|c|c|c|c|}
\hline $\begin{array}{l}\text { Acid Parts } \\
\text { in } 1, \infty 00, \infty 00\end{array}$ & $\begin{array}{l}\text { Hydrogen } \\
\text { Parts in } \\
x, 000,000\end{array}$ & Normality & $\begin{array}{l}\text { Per Cent of } \\
\text { Dissociation }\end{array}$ & $\begin{array}{c}\text { Dissociated } \\
\text { Hydrogen. } \\
\text { Parts in } \\
\mathrm{I}, \infty \infty, \infty \infty 0\end{array}$ & $\begin{array}{c}\text { Bacteria per } \\
\text { c.c. before } \\
\text { Treatment }\end{array}$ & $\begin{array}{c}\text { Percentage } \mathrm{Re}^{-} \\
\text {duction of Bac- } \\
\text { teria after } 40 \\
\text { Min. }\end{array}$ \\
\hline 29.23 & 0.24 & 0.0002 & 40.0 & 0.10 & 50,000 & 44.00 \\
\hline $\mathrm{J} 40.30$ & I. I 5 & 0.0011 & 20.3 & 0.23 & & 54.00 \\
\hline 243.80 & 2.00 & 0.0020 & $\mathrm{I}_{5} \cdot 4$ & $0.3 I$ & “ & 62.00 \\
\hline 333.00 & 2.73 & 0.0027 & I 3.6 & 0.37 & " & 70.00 \\
\hline 427.00 & $3 \cdot 52$ & 0.0035 & IO. 4 & 0.37 & $"$ & 92.00 \\
\hline 689.00 & $5 \cdot 75$ & 0.0057 & 9.8 & 0.56 & " & 100.00 \\
\hline $1,292.00$ & 10.60 & 0.0106 & 7.2 & 0.76 & " & 100.00 \\
\hline
\end{tabular}

the 100 per cent reduction at 0.0935 normal. The acid at these strengths is only a little over I per cent dissociated, and the amount of dissociated hydrogen present a little over I.2 parts per million. Since this is only about one-sixth the strength of ionic hydrogen necessary to produce similar results with the mineral acids, it is evident that the toxic action of the acetic acids is due chiefly to the anion or the undissociated molecule, the latter, being so much greater in 
amount, probably playing the principal part. The same thing is true of benzoic acid. Here the molecule is more highly toxic, producing a 99 per cent reduction at 0.0097 normality and a roo per cent reduction at 0.0199 normality, with about I per cent dissociation. As in the case of the mineral acids $B$. typhi is more sensitive than $B$. coli, showing too per cent reduction with benzoic acid at a strength of 0.0057 normal.

It appears, then, that the toxicity of these organic acids is duc not mainly to hydrogen ions, but to the action of the undissociated molecule, varying widely, as might be expected, with the acid employed. A comparison of the corresponding toxic normal

TABLE 9.

Toxicity of Organic and Mineral Acids for B. coli and B. typhi. Strength in Normality Producing go Per Cent and roo Per Cent Reduction.

\begin{tabular}{|c|c|c|c|c|}
\hline \multirow[b]{2}{*}{ Acid } & \multicolumn{2}{|c|}{ B. coli } & \multicolumn{2}{|c|}{ B. $t y p h i$} \\
\hline & $99 \%$ Reduction & I00\% Reduction & $99 \%$ Reduction & I00\% Reduction \\
\hline 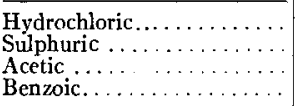 & $\begin{array}{l}0.0077 \\
0.0066 \\
0.0812 \\
0.0097\end{array}$ & $\begin{array}{l}0.0123 \\
0.0166 \\
0.0935 \\
0.0199\end{array}$ & $\begin{array}{l}0.0030 \\
0.0028 \\
\cdots \\
\cdots\end{array}$ & $\begin{array}{l}0.0050 \\
0.0045 \\
\ldots 045 \\
0.0057\end{array}$ \\
\hline
\end{tabular}

strength, made in Table 9, shows that benzoic acid is almost as toxic as the mineral acids, the effect being due in one case to the whole molecule, and in the other case to hydrogen ions. Acetic acid, on the other hand, has only Io-20 per cent as high a disinfectant action.

\section{THE DIMINISHED TOXICITY OF ACIDS IN THE PRESENCE OF PEPTONE.}

Having fixed with some precision the killing-point for the various acids studied, when acting in tap water, we next desired to determine what would occur in the presence of organic matter. A series of experiments was carried out, parallel to those reported above, except that a I per cent solution of Witte's peptone was used instead of tap water. The results with the mineral acids, presented in Tables ro-I 2, showed that the toxicity of the acid is profoundly modified by the presence of organic matter. 
Effect of Acids on Typhoid and Colon Bacilis 565

TABLE Io.

Disinfectant Action of Hydrochloric Acid on $B$. coli in a per Cent Peptone Solution.

\begin{tabular}{|c|c|c|c|c|c|c|}
\hline $\begin{array}{l}\text { Acid Parts in } \\
x, \infty \infty 0, \infty 00\end{array}$ & $\begin{array}{c}\text { Hydrogen } \\
\text { Parts in } \\
x, \infty 00,000\end{array}$ & Normality & $\begin{array}{c}\text { Per Cent } \\
\text { of } \\
\text { Dissociation }\end{array}$ & $\begin{array}{c}\text { Dissociated } \\
\text { Hydrogen. } \\
\text { Parts in } \\
\mathbf{1}, \infty 00, \infty 00\end{array}$ & $\begin{array}{l}\text { Bacteria per } \\
\text { c.c. before } \\
\text { Treatment }\end{array}$ & $\begin{array}{c}\text { Percentare } \\
\text { Reduction of } \\
\text { Bacteria after } \\
40 \mathrm{Min} .\end{array}$ \\
\hline $\begin{array}{l}I, I 18 \\
I, 825 \\
2,502 \\
2,950 \\
3,470 \\
3,685 \\
4,020\end{array}$ & $\begin{array}{r}30.62 \\
50.00 \\
69.00 \\
80.80 \\
95.20 \\
97.80 \\
110.00\end{array}$ & $\begin{array}{l}0.0306 \\
0.0500 \\
0.0690 \\
0.0808 \\
0.0952 \\
0.0978 \\
0.1100\end{array}$ & $\begin{array}{l}94.8 \\
94.8 \\
93.0 \\
92.0 \\
91.5 \\
91.4 \\
\ldots . .\end{array}$ & $\begin{array}{l}29.0 \\
47 \cdot 5 \\
64.2 \\
74.4 \\
87 \cdot 5 \\
89.4 \\
\ldots . .\end{array}$ & $\begin{array}{c}90,000 \\
\text { " } \\
4 \\
4 \\
16\end{array}$ & $\begin{array}{r}40.00 \\
93.35 \\
97.97 \\
97.74 \\
99.98 \\
100.00 \\
100.00\end{array}$ \\
\hline
\end{tabular}

TABLE II.

Disinfectant Action of Sut.phuric Acid on B. coli in a per Cent Peptone Solution.

\begin{tabular}{|c|c|c|c|c|c|c|}
\hline $\begin{array}{l}\text { Acid Parts } \\
\text { in } \\
1, \infty 00, \infty \infty 0\end{array}$ & 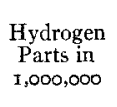 & Normality & $\begin{array}{c}\text { Per Cent } \\
\text { of } \\
\text { Dissociation }\end{array}$ & $\begin{array}{c}\text { Dissociated } \\
\text { Hydrogen. } \\
\text { Parts in } \\
\text { I, }, 000,000\end{array}$ & $\begin{array}{l}\text { Bacteria per } \\
\text { c. c. before } \\
\text { Treatment }\end{array}$ & $\begin{array}{c}\text { Percentage } \\
\text { Reduction of } \\
\text { Bacteria after } \\
40 \text { Min. }\end{array}$ \\
\hline $\begin{array}{r}970 \\
\mathbf{I}, 204 \\
\mathbf{I}, 405 \\
\mathbf{1}, 536 \\
\mathbf{1}, 728 \\
\mathbf{I}, 962 \\
2,066 \\
2,399 \\
2,639 \\
2,912 \\
3,065 \\
3,258 \\
3,450 \\
4,610 \\
5,298 \\
6,555 \\
7,800\end{array}$ & $\begin{array}{r}\ldots \ldots \\
\ldots \ldots \\
\ldots \ldots \\
31.4 \\
35.3 \\
40.1 \\
40.9 \\
48.9 \\
53.8 \\
59.4 \\
62.6 \\
66.5 \\
70.4 \\
94.2 \\
108.1 \\
135.2 \\
159.3\end{array}$ & $\begin{array}{l}\ldots \ldots \\
\ldots \ldots \\
\ldots \ldots \ldots \\
0.0314 \\
0.0353 \\
0.0401 \\
0.0409 \\
0.0489 \\
0.0538 \\
0.0594 \\
0.0626 \\
0.0665 \\
0.0700 \\
0.0942 \\
0.1081 \\
0.1352 \\
0.1593\end{array}$ & $\begin{array}{l}\ldots . \\
\ldots . \\
\ldots . \\
70.0 \\
68.5 \\
67.5 \\
67.0 \\
65.4 \\
64.8 \\
64.2 \\
63.2 \\
62.8 \\
61.9 \\
58.9 \\
57.0 \\
\ldots \\
\ldots\end{array}$ & $\begin{array}{l}\ldots . \\
\ldots \\
\ldots \ldots \\
22.0 \\
24.2 \\
27.1 \\
27.4 \\
32.0 \\
24.9 \\
38.1 \\
30.6 \\
41.8 \\
43.5 \\
55.5 \\
61.6 \\
\ldots \ldots \\
\ldots \ldots\end{array}$ & 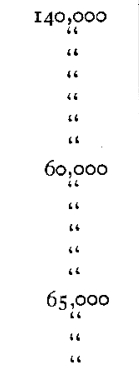 & $\begin{array}{r}00.00 \\
00.00 \\
00.00 \\
00.00 \\
20.00 \\
61.43 \\
64.29 \\
76.67 \\
79.17 \\
91.67 \\
93.33 \\
94.17 \\
98.85 \\
99.99 \\
100.00 \\
100.00 \\
100.00\end{array}$ \\
\hline
\end{tabular}

TABLE I2.

Disinfectant Action of Hydrochloric Acid on B. typhi in i Per Cent Peptone Solution.

\begin{tabular}{|c|c|c|c|c|c|c|}
\hline $\begin{array}{l}\text { Acid Parts } \\
\text { in } \\
\mathrm{I}, 000,000\end{array}$ & 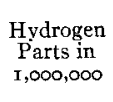 & Normality & $\begin{array}{l}\text { Per Cent of } \\
\text { Dissociation }\end{array}$ & $\begin{array}{l}\text { Dissociated } \\
\text { Iydurogen. } \\
\text { Parts in } \\
1, \infty 00,000\end{array}$ & $\begin{array}{c}\text { Bacteria per } \\
\text { c.c. before } \\
\text { Treatment }\end{array}$ & $\begin{array}{c}\text { Percentage } \\
\text { Reduction of } \\
\text { Bacteria after } 40 \\
\text { Min. }\end{array}$ \\
\hline 1,107 & $\begin{array}{l}30 \cdot 3 \\
47.6\end{array}$ & $\begin{array}{l}0.0330 \\
0.0476\end{array}$ & $\begin{array}{l}94.8 \\
93.8\end{array}$ & $\begin{array}{l}28.7 \\
44.6\end{array}$ & $\begin{array}{l}50,000 \\
50,000\end{array}$ & $\begin{array}{r}99.99 \\
100.00\end{array}$ \\
\hline 1,740 & 47.0 & & & & & \\
\hline
\end{tabular}

In these tables the dissociation values given are those determined for distilled water, and not those which actually obtain in a peptone solution. The amount of dissociated hydrogen required for disinfection, when estimated in this way, is seen to be ncarly to times as great as in tap water. For comparison the results are brought together in Table $\mathbf{4} 4$. 
TABLE I3.

Disinfectant Action of Sulphuric Acid on $B$.typhi in I Per Cent Peptone Solution.

\begin{tabular}{|c|c|c|c|c|c|c|}
\hline $\begin{array}{c}\text { Acid Parts } \\
\text { in } \\
I, 000,000\end{array}$ & $\begin{array}{c}\text { Hydrogen } \\
\text { Parts in } \\
1,000,000\end{array}$ & Normality & $\begin{array}{c}\text { Per Cent } \\
\text { of } \\
\text { Dissociation }\end{array}$ & $\begin{array}{c}\text { Dissociated } \\
\text { Hydrogel. } \\
\text { Parts in } \\
1, \infty 00,000\end{array}$ & $\begin{array}{l}\text { Bacteria per } \\
\text { c. c. before } \\
\text { Treatment }\end{array}$ & $\begin{array}{c}\text { Percentage } \\
\text { Reduction of } \\
\text { Bacteria after } \\
40 \mathrm{Min} .\end{array}$ \\
\hline $\begin{array}{r}819 \\
960 \\
1,104 \\
1,139 \\
1,288 \\
1,453 \\
1,472 \\
1,519 \\
1,587 \\
1,612 \\
1,678 \\
1,879 \\
1,994 \\
2,045 \\
2,115 \\
2,119 \\
2,399\end{array}$ & $\begin{array}{l}17.03 \\
20.00 \\
22.52 \\
23.17 \\
26.32 \\
29.63 \\
30.03 \\
31.66 \\
32.39 \\
32.89 \\
34.24 \\
38.32 \\
\ldots . \\
\ldots . \\
\ldots . \\
\ldots . \\
\ldots .\end{array}$ & $\begin{array}{l}0.0170 \\
0.0200 \\
0.0225 \\
0.0232 \\
0.0265 \\
0.0296 \\
0.0300 \\
0.0317 \\
0.0324 \\
0.0329 \\
0.0342 \\
0.0383 \\
\ldots \ldots \\
\ldots \ldots \\
\ldots \ldots \\
\ldots \ldots \\
\ldots \ldots\end{array}$ & $\begin{array}{l}74.5 \\
73.7 \\
72.0 \\
72.0 \\
71.0 \\
70.2 \\
70.1 \\
69.7 \\
69.5 \\
69.0 \\
68.5 \\
68.0 \\
\ldots \ldots \\
\ldots \ldots \\
\ldots \ldots \\
\ldots \ldots\end{array}$ & $\begin{array}{l}\text { I2.7 } \\
14.7 \\
16.2 \\
16.7 \\
18.7 \\
20.8 \\
21.0 \\
21.6 \\
22.5 \\
22.7 \\
23.4 \\
26.0 \\
\ldots . \\
\ldots . \\
\ldots \ldots \\
\ldots \ldots \\
\ldots .\end{array}$ & $\begin{array}{c}85,000 \\
" 6 \\
" 6 \\
4 \\
28,000 \\
85,000 \\
28,000 \\
4 \\
4 \\
4 \\
4 \\
4 \\
4 \\
4\end{array}$ & $\begin{array}{r}00.00 \\
17.65 \\
17.65 \\
34.10 \\
61.20 \\
82.15 \\
76.45 \\
80.30 \\
89.30 \\
100.00 \\
97.86 \\
100.00 \\
100.00 \\
100.00 \\
100.00 \\
100.00 \\
100.00\end{array}$ \\
\hline
\end{tabular}

TABLE I4.

Comparative Toxictiy of Mineral Acids in Distilled Water and i per Cent Peptone Solution. (Parts per $\mathrm{I}, \infty 00,000$ of dissociated hydrogen.)

\begin{tabular}{|c|c|c|c|c|c|c|c|c|}
\hline & \multicolumn{4}{|c|}{ B. coli } & \multicolumn{4}{|c|}{ B. $t y p h i$} \\
\hline & \multicolumn{2}{|c|}{$99 \%$ Reduction } & \multicolumn{2}{|c|}{ I00\% Reduction } & \multicolumn{2}{|c|}{$99 \%$ Reduction } & \multicolumn{2}{|c|}{ 100\% Reduction } \\
\hline & $\mathrm{HCl}$ & $\mathrm{H}_{2} \mathrm{SO}_{4}$ & $\mathrm{HCl}$ & $\mathrm{H}_{2} \mathrm{SO}_{4}$ & $\mathrm{HCl}$ & $\mathrm{H}_{2} \mathrm{SO}_{4}$ & $\mathrm{HCl}$ & $\mathrm{HO}_{4}$ \\
\hline $\begin{array}{l}\text { Distilled water........... } \\
\text { I per cent peptone...... }\end{array}$ & 87.49 & $\begin{array}{l}7.68 \\
55.5\end{array}$ & $\begin{array}{l}\text { II } 80 \\
89.4\end{array}$ & $\begin{array}{l}12.60 \\
61.6\end{array}$ & $\begin{array}{l}2.94 \\
28.7\end{array}$ & $\begin{array}{l}2.54 \\
\cdots\end{array}$ & $\begin{array}{r}4.85 \\
44.6\end{array}$ & $\begin{array}{l}3.90 \\
22.7\end{array}$ \\
\hline
\end{tabular}

It is evident that in some way the peptone exerts a strong influence in counteracting the toxic effect of the acids. It at first occurred to us that this might be due simply to the fact that peptone solution furnished a more favorable medium for the bacteria, and thus enabled them to resist unfavorable conditions. Such an effect would, however, hardly be expected in so short a period as 40 minutes; and this explanation fails to account for the fact that the toxicity of the hydrochloric acid is much more diminished than that of the sulphuric acid. Reference to Tables I $^{-17}$, which show the results obtained with the organic acids, makes it still clearer that a specific chemical action is involved.

Evidently with the organic acids disinfectant power is much less affected by the presence of peptone. With $B$. coli acetic acid produces a Ioo per cent reduction when in a strength of 0.0935 
Effect of Acids on Typhoid and Colon Bacilli 567

TABLE I5.

Disinfectant Actiondf Acettc Acid on B. coli in t Per Cent Peptone Solution.

\begin{tabular}{|c|c|c|c|c|c|c|}
\hline $\begin{array}{l}\text { Acid Parts } \\
\text { in } 1,000,000\end{array}$ & $\begin{array}{l}\text { Hydrogen } \\
\text { Parts in } \\
1, \infty 00,000\end{array}$ & Normality & $\begin{array}{l}\text { Per Cent of } \\
\text { Dissocia- } \\
\text { tion }\end{array}$ & $\begin{array}{l}\text { Dissociated } \\
\text { Hydrogen. } \\
\text { Parts in } \\
1, \infty 00, \infty 00\end{array}$ & $\begin{array}{l}\text { Bacteria } \\
\text { per c.c. } \\
\text { before } \\
\text { Treatment }\end{array}$ & $\begin{array}{c}\text { Percentage Re- } \\
\text { duction of Bac- } \\
\text { teria after } 40 \\
\text { Min. }\end{array}$ \\
\hline 4,350 & $72 \cdot 5$ & 0.0725 & 1.60 & I. 16 & 50,000 & 00.00 \\
\hline 4,750 & $79 \cdot 3$ & 0.0793 & I. 50 & I. 19 & "6 & 00.00 \\
\hline 5,340 & 89.0 & 0.0890 & 1.40 & I. 25 & 6 & 25.00 \\
\hline 5,975 & 97.0 & 0.0970 & I. 30 & 1.26 & 6 & 66.00 \\
\hline 5,095 & 98.0 & 0.0980 & I. 30 & 1.27 & “6 & $61 \cdot 72$ \\
\hline 6,861 & I 14.2 & 0.1142 & I. 25 & I. 42 & $6_{5,000}$ & 98.75 \\
\hline 7,540 & 125.8 & $0,125^{8}$ & I. I5 & I. 45 & 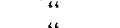 & $93 \cdot 30$ \\
\hline 8,360 & 139.5 & o. r395 & 1.05 & I. 46 & $"$ & 100.00 \\
\hline 9,125 & I52. I & $0.152 \mathrm{I}$ & 1.03 & I. 57 & $" 6$ & 100.00 \\
\hline 16,475 & I74. 5 & 0.1745 & 1.00 & I. 75 & ، & 100.00 \\
\hline 10,720 & 178.8 & o. 1788 & $1 . \infty 0$ & $1 \cdot 78$ & 6 & $\ldots$ \\
\hline$\ldots$ & 210.0 & 0.2100 & $\ldots \ldots$ & $\ldots$ & "4 & $\ldots \ldots$ \\
\hline 14,620 & 244.0 & 0.2440 & 0.90 & 2.20 & & 100.00 \\
\hline
\end{tabular}

TABLE I6.

Disinfectant Action of Benzoic Acid on B. coli in i per Cent Peptone Solution.

\begin{tabular}{|c|c|c|c|c|c|c|}
\hline $\begin{array}{l}\text { Acid Parts } \\
\text { in } 1,000,000\end{array}$ & $\begin{array}{l}\text { Hydrogen } \\
\text { Parts in } \\
x, \infty \infty 0, \infty \infty 0\end{array}$ & Normality & $\begin{array}{l}\text { Per Cent of } \\
\text { Dissocia- } \\
\text { tion }\end{array}$ & $\begin{array}{c}\text { Dissociated } \\
\text { Hydrogen. } \\
\text { Parts in } \\
\mathrm{I}, \infty 00, \infty 00\end{array}$ & $\begin{array}{l}\text { Bacteria } \\
\text { per c.c. } \\
\text { before } \\
\text { Treatment }\end{array}$ & $\begin{array}{c}\text { Percentage Re- } \\
\text { duction of Bac- } \\
\text { teria after } 40 \\
\text { Min. }\end{array}$ \\
\hline $\mathrm{r}, 63_{3} 8$ & 13.18 & 0.0132 & 6.4 & 0.84 & 70,000 & 28.6 \\
\hline 1,720 & I4. II & 0.0141 & 6.2 & 0.87 & 70,000 & 28.6 \\
\hline 2,105 & I 7.20 & 0.0172 & 5.8 & $1 . \infty$ & 100,000 & 0.0 \\
\hline 3,365 & 27.60 & 0.0276 & $5 \cdot 2$ & I. 43 & 100,000 & 73.0 \\
\hline 5,555 & $47 \cdot 30$ & 0.0473 & 3.2 & I. $5 \mathrm{I}$ & 100,000 & 100.0 \\
\hline
\end{tabular}

TABLE 17 .

Disinfectant Action of Benzoic Acid on B. typhi in u per Cent Peptone Solution.

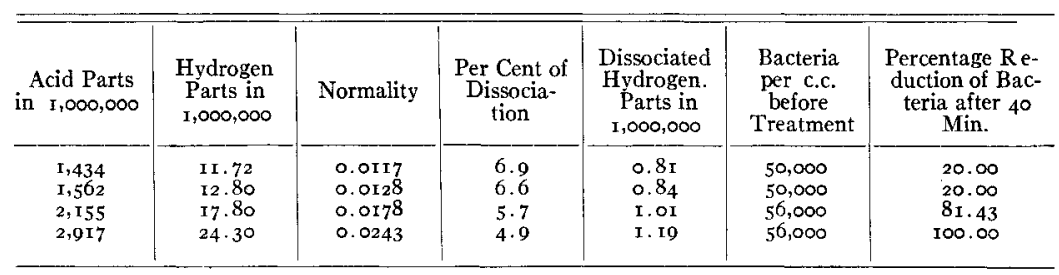

normal. In the presence of peptone the required strength is O.I395 normal. With $B$. coli the corresponding roo per cent reduction strengths for benzoic acid are 0.0199 in water and 0.0473 in peptone solution. With B. typhi the respective strengths of benzoic acid are 0.0057 and 0.0243 .

In a general way we may say that the presence of I per cent peptone solution diminishes the toxicity of hydrochloric acid, measured in terms of dissociated hydrogen, to from one-eighth to one-tenth its water value, and that of sulphuric acid to from one-fifth to one-eighth 
its water value. The toxicity of benzoic acid, measured in normality, is diminished under the same conditions to from one-fourth to onehalf, and that of acetic acid to a little over one-half its water value.

The most probable explanation of this phenomenon is the formation of a loose compound between the proteid molecules and the acids which would diminish the toxicity of the latter, just as Stiles and Beers (I905) have shown that such a combination alters the effect of mineral salts on muscle.

Bugarzky and Liebermann (I898), Cohnheim and Krieger (I900), and other observers, have proved the existence of such loose compounds between proteids and acids by freezing-point determinations. We desired, however, to examine the actual substance used in our own experiments. Through the kindness of Dr. Raymond Haskell, of the Research Laboratory of Physical Chemistry of this Institute, determinations of electrical conductivity were made on the peptone solution used in our experiments, on a solution of hydrochloric acid in distilled water, and on a solution of the same strength in the peptone solution.

The specific conductivity of the peptone solution was 0.0004 , showing that it was fairly pure. That of the hydrochloric acid solution 0.02 normal or 720 parts $\mathrm{HCl}$ per million, 90.46 per cent dissociated, was 0.007 . The I per cent peptone solution containing 0.02 normal hydrochloric acid gave a conductivity of 0.002 , showing that approximately four-fifths of the hydrochloric acid had been neutralized by the peptone.

It is evident that the effect of the peptone in decreasing the toxicity of the hydrochloric acid may be explained by the fact that the number of dissociated hydrogen ions is decreased by the peptone in the same degree. The effect would naturally be less marked, as we find to be the case, with sulphuric acid, since this acid is less ionized to start with. Finally, the un-ionized organic acids are least affected. The decreased toxicity which does occur with them may perhaps be due to a loose compound with their whole-molecule-what Stiles and Beers call a "physiological compound."

\section{GENERAL CONCLUSIONS.}

It appears from our experiments that the typhoid bacillus is highly sensitive to an excess of acid, being destroyed in an aqueous suspen- 
sion by 40 minutes' exposure to a 0.005 normal solution of either hydrochloric, sulphuric or benzoic acid. The colon bacillus will endure exposure, under similar conditions, to solutions from two to four times as strong. Ninety-nine per cent of the bacteria in a suspension are killed by solutions of from one-half to two-thirds this strength, the last few organisms being especially resistant.

The mineral acids, hydrochloric and sulphuric, are fatal in concentrations at which they are highly dissociated. Their action runs parallel, not to their normal strength, but to the number of free hydrogen ions per unit volume. With the two organisms tested, both the 99 per cent and the roo per cent reductions were affected, at the same concentration of dissociated hydrogen, whichever acid was used.

The organic acids, acetic and benzoic, are fatal to the typhoid and colon bacilli at a strength at which they are only slightly dissociated. The effect here appears to be due to the whole-moleculc and is specific for each acid, acetic having only 10-20 per cent the toxicity of benzoic.

The presence of I per cent of peptone greatly diminishes the toxic action of acids, the action being somewhat less marked with sulphuric acid than with hydrochloric, and still weaker with the organic acids. In the case of hydrochloric acid we find that the diminished toxicity is accounted for by decreased ionization.

It is evident that the action of organic matter and other neutral substances in decreasing toxicity greatly complicates the study of disinfectant action. It will be necessary to bear this phenomenon in mind in considering the composition of culture media, since the apparent acidity, as determined by titration, may be quite different from the effective acidity which influences living organisms. With the mineral acids, any factor which affects dissociation, such as the presence of neutral salts of the same anion, will change the effective acidity. In considering the viability of disease germs in sewage and water, it is evident that differences in dilution and the effect of inorganic salts, organic matter, and suspended solids introduce such complex factors that detailed studies of specific local conditions are desirable. 


\section{REFERENCES.}

Beckmann, J. W. i896. Ueber den Einfluss des Zusatzes von Chlornatrium auf die Wirkung des Phenols. Centralbl. f. Bakt., Abth. I, 20, p. 577 .

Behring. I89o. Ueber Desinfection, Desinfectionsmittel und Desinfectionsmethoden. Ztschr. f. Hyg., 9, p. 395 .

BIAL, M. I897. Ueber den Mechanismus der Gasgährungen im Magensafte. Arch. f. exper. Path. u. Pharm., 38, p. I.

BIAL, M. IgO2. Ueber die antiseptische Funktion des H-Ions verdünnter Saüren. Ztschr. f. phys. Chemie., 40, p. $5 \mathrm{I} 3$.

Bugarszky, S., ANd Liebermann, L. I898. Ueber das Bindungsvermögen eiweissartiger Körper für Salzsaüre, Natriumhydroxid und Kochsalz. Arch. f. d. ges. Physiol., 72, p. 5I.

Clark, J. F. I899. On the Toxic Effect of Deleterious Agents on the Germination and Development of Certain Filamentous Fungi. Bot. Gazette, 28, p. 289; also, Jour. Phys. Chem., 3, p. 203.

CoHen, E. 1903. Physical Chemistry for Physicians and Biologists. Trans. by M. H. Fischer, New York, I903.

CoHnheim, O., AND KrIeger, H. igoo. Das Verhalten der Eiweisskörper zu Alkaloidreagentien zugleich eine Bestimmung der gebundenen Salzsaüre. Ztschr. f. Biol., 40, p. 95 .

Dreser, H. I893. Zur Pharmakologie des Quecksilbers. Arch. f. exper. Path. u. Pharm., 32, p. 456 .

Frost, W. D., And Swenson, M. W. 19o6. Note on the Thermal Death-Point of B. dysenteriae Shiga. Science, N. S., 23, p. 216.

Gage, S. D., and Stoughton, G. van E. Igo6. A Study of the Laws Governing the Resistance of B. Coli to Heat. Science, N. S., 23, p. 216.

HAMBURger, H. J. Ig04. Osmotischer Druck und Ionlehre in den medicinischen Wissenschaften. Wiesbaden, 1904.

Heald, F. D. I896. On the Toxic Effect of Dilute Solutions of Acids and Salts upon Plants. Bot. Gazette, 22, p. I25.

HEIDER, A. I892. Ueber die Wirksamkeit der Desinfectionsmittel bei erhöhter Temperatur. Arch. f. Hyg., 15, p. 34r.

JoHnson, G. A. 1905. The Use of Copper Sulphate for Reducing the Pathogenicity of Sewage and Sewage Eflluents. Jour. New Eng. Waterworks Assoc., I9, p. 506 .

Kahlenberg, L. I898. The Action of Solutions on the Sense of Taste. Bull. University of Wisconsin, 2, p. I.

Kahlenberg, L., and True, R. H. I896. On the Toxic Action of Dissolved Salts and Their Electrolytic Dissociation. Bot. Gazette, 22, p. 81.

Косн, R. I88I. Ueber Desinfection. Mith. a. d. kaiserlichen Gesundheitsamte, r, p. $\mathrm{I}$.

KRöNIG, B., AND PAUL, T. I897. Die chemischen Grundlagen der Lehre von der Giftwirkung und Desinfection. Zischr. f. Hyg., 25, p. I.

LOEB, J. I897. Physiologische Untersuchungen über Ionenwirkungen, I. Arch. f. d. ges. Physiol., 69, p. I.

LoEB, J. I898. Physiologische Untersuchungen über Ionenwirkungen, II. Arch. f. d. ges. Physiol., 7I, p. 457 . 
Loeb, J. 1905. Studies in General Physiology. Decennial Publications of the University of Chicago, Chicago, 1905 .

Maillard, L. I8g8. Du rôle de l'ionisation dans les phénomènes vitaux. Comptes rend. de la Soc. de Biol., 50, p. т210.

MaIllard, L. 1899. Rôle de l'ionisation dans la toxicité des sels métalliques; sulfate de cuivre et Penicillium glaucum. Bull. Soc. chim. Paris, 21, p. 26.

MinervinI, R. I898. Ueber die baktericide Wirkung des Alkohols. Ztschr. f. Hyg., 29, p. II7.

NÄGELI, C. voN. I893. Ueber oligodynamische Erscheinungen in lebenden Zellen. Neue Denkschriften der allgemeinen Schweizerischen Gesells. f. d. ges. Naturwissenschaften, 33, Abth. I.

Paul, T., and Krönig, B. I8g6. Ueber das Verhalten der Bakterien zu chemischen Reagentien. Ztschr f. phys. Chemie, 2I, p, 4I4-

RöMer, C. I898. Ueber Desinfection von Milzbrandsporen durch Phenol in Verbindung mit Salzen. Mïnch. med. Wchnschr., 45, p. 298.

Scheurlen. 1895. Die Bedeutung des Molecularzustandes der wassergelösten Desinfectionsmittel für ihren Wirkungswerth. Arch. f. exper. Path. u. Pharm., 37, p. 74 .

SCHEURLEN AND SPIRO. I897. Die gesetzmässigen Beziehungen zwischen Lösungszustand und Wirkungswerth der Desinfectionsmittel. Münch. med. Wchnschr., 44 , p. $8 \mathrm{I}$.

Sedgwick, W. T., ANd Winslow, C.-E. A. igo2. Experiments on the Effect of Freezing and Other Low Temperatures upon the Viability of the Bacillus of Typhoid Fever, with Considerations, Regarding Ice as a Vehicle of Infectious Disease. Memo. Amer. Acad. Arts and Sciences, 12, p. 47 ז.

Spiro, K., ANd Bruns, H. I898. Zur Theorie der Desinfection. Arch. f. exper. Path. u. Pharm., 4I, p. 355 .

Stevens, F. L. 1898 . The Effect of Aqueous Solutions upon the Germination of Fungus Spores. Bot. Gazette, 26, p. 377.

StIles, P. G., AND BeERs, W. H. 1905. On the Masking of Familiar Ionic Effects by Organic Substances in Solutions. Amer. Jour. Physiol., I4, p. I33.

True, R. H., and Oglevee, C. S. I905. The Effect of the Presence of Insoluble Substances on the Toxic Action of Poisons. Bot. Gazette, 39, p. I.

WÜтHRICH. I892. Ueber die Einwirkung von Metallsalzen und Saüren auf die Keimfähigkeit der Sporen einiger der verbreitetsten parasitischen Pilze unserer Culturpflanzen. Ztschr. f. Pflanzenkrankheiten, 2, p. I7. 